\title{
Faktori uspješnosti upravljanja gradskim nekretninama u Hrvatskoj
}

\author{
Marko Ignjatovic * \\ https://doi.org/10.31297/hkju.20.1.6 \\ UDK 352.07:351.712.045(497.5) \\ 352.07:347.232(497.5) \\ 352.07:349.418(497.5) \\ Original scientific paper / izvorni znanstveni rad \\ Received / primljeno: 23.7.2019. \\ Accepted / prihvaćeno: 10.1.2020.
}

Jedinice lokalne samouprave u Republici Hrvatskoj u vlasništvu imaju velik broj različitih oblika imovine. Nekretnine su najvredniji oblik u portfelju nefinancijske imovine. To je vrsta imovine s najvećom vrijednošću kojom raspolažu i upravljaju gradovi. Navedene vrste nekretnina posredno su vlasništvo svih građana, zbog čega je bitno osigurati njihovo učinkovito upravljanje. Ovaj rad pokazuje kako su nekretnine slabo korišten izvor financiranja gradova, što se odražava i na pokazatelj povrata koji gradovi ostvaruju na temelju nekretnina u svojem vlasništvu. Također, u radu se panel-regresijom empirijski istražuju odrednice povrata na nekretnine u hrvatskim gradovima od 2005. do 2017., s posebnim naglaskom na kvalitetu gradske uprave kao važne odrednice iskorištenosti nekretnina. Zbog nedostatka kredibilnih i javno dostupnih indikatora o kvaliteti gradskih uprava, u ovom se

* Marko Ignjatović, doktorski student Ekonomskog fakultetu Sveučilišta u Zagrebu, Hrvatska (doctoral student at the Faculty of Economics, University of Zagreb, Croatia, e-mail: marko.ignjatović@spi.hr).

ORCID ID: https://orcid.org/0000-0002-7967-0095 
radu kao proxy varijablom za kvalitetu gradske uprave koristi broj poduzetnika po stanovniku. Takav se pristup temelji na Tieboutovu modelu glasanja nogama.

Ključne riječi: kvaliteta uprave, nekretnine, gradovi, učinkovitost upravljanja, povrat na nekretnine

\section{Uvod}

Tranzicijskim promjenama prije četvrt stoljeća nastale su znatne promjene u pristupu upravljanju nekretninama, pri čemu je ostvaren spor napredak u ispunjenju temeljnog uvjeta za uspješnije upravljanje nekretninama, a to su potpune i uređene evidencije o vrsti, namjeni, broju, vrijednosti te prihodima i rashodima na nekretninama. Bez uređenih evidencija teško je učinkovito upravljati imovinom (Dent, 2014). Uredne evidencije i javno provođenje postupaka upravljanja i raspolaganja (zakupi, najmovi, zamjene, prodaje, korištenje s valjanom pravnom osnovom i dr.) pretpostavka su transparentna upravljanja. To su ujedno preduvjeti da bi građani mogli prepoznati i ocijeniti kvalitetu upravljanja i pružiti/uskratiti potporu lokalnoj vlasti (izborima i referendumom ili drugim oblicima odlučivanja).

Upravljanje je na najosnovnijoj razini definirano kao proces koji podatke o nekretninama pretvara u radnju (Thorncroft, 1965). Naravno, gradovi nisu jedine institucije koje mogu odlučivati o učinkovitijem upravljanju i raspolaganju nekretninama lokalne zajednice. Naime, česti slučajevi neuređenih imovinskopravnih odnosa (posebice neuređeno stanje u zemljišnim knjigama) glavna su ograničenja učinkovitom upravljanju nekretninama lokalne zajednice. Stoga treba upozoriti i na česte probleme evidencije imovine između države i lokalnih jedinica zbog kojih dolazi do obustavljanja provedbe planiranih projekata. Korištenje nekretninama u lokalnoj zajednici treba biti usmjereno (Kaganova, McKellar \& Peterson, 2006): a) potrebama lokalne zajednice (komunalna infrastruktura, prometnice itd.) kao i svim zakonima definiranim obvezama (groblja, predškolski odgoj, mjesna samouprava i dr.); b) potpori društvenokorisnih, sportskih, kulturnih, nevladinih, političkih i drugih sadržaja; c) ostvarivanju prihoda prema tržišnim uvjetima za sve nekretnine.

I u većem dijelu zemalja u okruženju i u gradovima u Republici Hrvatskoj upravljanje nekretninama koje su u njihovu vlasništvu složen je i zahtjevan posao. Taj izazov proizlazi iz prošlosti kao rezultat tranzicije političkog sustava, nesređenih evidencija o nekretninama i nasljeđivanja velika 
broja nekretnina preko instrumenta pravnog sljedništva. U odnosnu na središnju državu gradovi su proteklih 20-ak godina kvalitetnije ustrojili evidencije (Bajo \& Ignjatović, 2018) i primarno se bavili rješavanjem imovinskopravnih odnosa, a manje sustavnim upravljanjem nekretninama menadžerskim pristupom.

Pitanja raspolaganja nekretninama, određivanja vlasništva (Simonetti, 2010) ili drugih stvarnih prava uređena su brojnim zakonima i podzakonskim propisima. Međutim, tek je nekoliko zakona koji djelomično reguliraju ulogu gradova u upravljanju nekretninama. Sličan izazov imaju i lokalne vlasti u drugim državama kada se susreću s nejasnim pravnim i institucijskim okvirom za potporu upravljanju nekretninama (Hanis, Trigunarsyah \& Susilawati, 2010a).

Budući da nekretnine u vlasništvu gradova imaju veliko društveno i ekonomsko značenje, potrebno je promatrati sve čimbenike koji mogu utjecati na učinkovitost upravljanja navedenim nekretninama. U skladu s navedenim, temeljni je cilj ovog rada empirijski istražiti temeljne odrednice učinkovitosti upravljanja nekretninama u vlasništvu gradova u Republici Hrvatskoj analizom različitih ekonomskih, fiskalnih, socio-ekonomskih i institucijskih čimbenika. Istraživanje u ovom radu temelji se na modelima panel-regresije, a uzorak istraživanja obuhvaća 126 gradova od 2005. do 2017. godine.

Osnovni doprinos rada očituje se upravo u empirijskom istraživanju koje je prvo istraživanje takva tipa u literaturi. Kako je objašnjeno u nastavku, dosadašnja istraživanja bila su usmjerena na različite aspekte upravljanja nekretninama u lokalnim jedinicama, ali, prema saznanju autora, dosad nije provedena slična analiza temeljnih odrednica učinkovitosti upravljanja nekretninama u lokalnim jedinicama.

\section{Pregled literature}

Važnost problematike upravljanja nekretninama gradova, koja je predmet istraživanja ovog rada, potvrđuje i veći broj dosad objavljenih radova. Dio radova usmjeren je na upravljanje nekretninama na razini središnje države (Kask, 2014), posebice na analize pojedinih segmenata upravljanja (baze podataka, vrednovanje) u područjima pojedinih država (na lokalnoj razini). Istaknutiji radovi na temu upravljanja imovinom prisutni su kod autora Hanis, Trigunarsyah i Susilawati (2011), Phelps (2010), Kaganova, Tian i Undeland (2001). Većina se autora susretala s problemom priku- 
pljanja podataka, što je otežalo provedbu istraživanja, analizu podataka i donošenje relevantnih zaključaka.

Istraživači se nisu usuglasili oko podrijetla upravljanja nekretninama, ali postoji suglasje da se upravljanje razvilo iz drugih disciplina. Primjerice, Edwards i Ellison (2009) tvrde da je koncept upravljanja nekretninama relativno nov i obuhvaća aktivnosti koje su provođene i u prethodnom razdoblju fragmentirano, a razvile su se tijekom nekoliko desetljeća industrijskog doba. Tijekom razvojne faze upravljanje nekretninama prihvaća i implementira druge discipline i tehnike. Bez obzira na podrijetlo upravljanja nekretninama, organizacije javnog i lokalnog sektora počele su cijeniti njegove pozitivne učinke. Promatrajući upravljanje nekretninama u gradovima diljem svijeta, uočit će se nekoliko identičnih okolnosti. Decentralizacijama su lokalne samouprave gotovo preko noći postale „nekretninski divovi“, odnosno novi nositelji vlasništva nekretnina (Hentschel \& Kaganova, 2007). Međutim, navedenu transformaciju ne prati povećanje prihoda potrebnih za uredno evidentiranje promjena i održavanje navedenih nekretnina (Banner \& Gagne, 1995).

Dosadašnje studije u svijetu bavile su se učinkovitošću upravljanja nekretninama središnje države (Kask, 2014), zatim načinima korištenja nekretninama u vlasništvu lokalne samouprave (Wilson, 2013). Neki od radova istraživali su fiskalni kapacitet i prikupljanje prihoda od upravljanja nekretninama (Banner \& Gagne, 1995), dok se ostala većina radova fokusirala na analizu i način upravljanja nekretninama na lokalnoj razini (Kaganova, McKellar \& Peterson, 2006). Dio domaćih istraživanja odnosio se na analizu vrsta nekretnina kojima gradovi upravljaju i njihov pravni status (Kontrec, 2014), a dio je radova istraživao nekretnine u vlasništvu gradova i njihov način upravljanja odnosno metode evidentiranja (Guszak, 2007). Određeni dio studija usmjerio se na analizu i metodologiju usklađenja financijske vrijednosti nekretnina u vlasništvu lokalne samouprave (Vašiček, 2015).

\section{Osnovna obilježja nekretnina u gradovima}

Učinkovito upravljanje prostornim resursima jedan je od glavnih čimbenika zdrava gospodarskog rasta. Produktivno upravljanje nekretninama od njihovih vlasnika očituje se u sustavnoj i učinkovitoj kontinuiranoj brizi koja rezultira ostvarivanjem planiranih rezultata, odnosno ciljeva koje ostvaruju uporabom nekretnina u svom vlasništvu. Stoga ovaj rad pro- 
matra upravljaju li gradovi učinkovito svojim nekretninama. Prije svega, nužno je dobro definirati pojam nekretnina u smislu ovog rada te njihovu ulogu i značenje.

Nekretnine su pojavni oblik imovine koje su fizički smještene u prostoru, one su vezane za određeno područje i kao takve ne mogu biti jednostavno premještene s jedne na drugu lokaciju. Osim zemljišta, nekretninama se smatraju i drugi pojavni oblici koji su vezani za samo zemljište, a određena su funkcionalna cjelina kao što su zgrade, ceste kao i sve ostale građevine. Za razliku od pokretnina, nekretnine zbog svoje vrijednosti imaju drukčija pravila raspolaganja i uživanja. Prava vlasništva na navedenim oblicima imovine (nekretninama) stječu se upisom u zemljišne knjige, dok se prava na pokretninama stječu prodajom. Iako imaju predviđeno trajanje, u pravilu korištenje nekretninama može trajati dulje nego što traje prosječan život njihovih vlasnika uz uvjet da se nekretnina održava. Nekretnine mogu biti korištene za osobne potrebe privatnih vlasnika, a isto se tako mogu upotrebljavati u poslovne svrhe radi obavljanja djelatnosti poslovnog subjekta ili mogu služiti za iznajmljivanje.

No, predmet su ovog rada nekretnine u vlasništvu gradova te u tom kontekstu takve nekretnine služe za obavljanje komunalnih djelatnosti, djelatnosti odgoja i obrazovanja, sport i rekreaciju stanovništva te ostale aktivnosti iz djelokruga gradova.

Nekretnina je zbog svojih fizičkih svojstava i oblika vrlo teško otuđiva bez traga te je zbog svoje vrijednosti i pojavnog oblika relativno sigurna i stabilna imovina pogodna kao instrument plaćanja kod različitih oblika kreditnog zaduživanja. U slučaju da dužnik ne namiri sve svoje obveze nakon ugovorenog financiranja u dogovorenim rokovima, postoji mogućnost da vjerovnik naplati svoja potraživanja iz vrijednosti same nekretnine. Osim nekretnine, svi oni njezini dijelovi koji čine funkcionalnu cjelinu ulaze u sastavni dio nje same i čine njezinu ukupnu vrijednost. Tako ako govorimo o kući, osim samog zemljišta i građevine, tu nekretninu čine i sve instalacije, oprema i ostali elementi koji su ugrađeni i koji čine tu cjelinu funkcionalnom.

U uvodu svoje knjige „Moderni menadžment nekretnina“ Pfnür (2005) zapaža izazov definiranja pojma nekretnina s obzirom na njegovo višestruko značenje u govornom, ali i u znanstvenom području te smatra da je prije ekonomskog definiranja pojam nužno definirati kao pravni s obzirom na to da se nekretnine prema vrsti i opsegu pravno određuju kao ekonomsko dobro u poslovnom prometu. Nadalje, autor raspravlja da je u okvirima pravne znanosti mnogo važniji pojam od nekretnina - zemljište - 
te da se nekretnine gotovo uopće i ne spominju. U općoj jezičnoj uporabi zemljište je povezana površina tla na nekom prostoru u prirodi, a najčešće je od drugih zemljišta fizički odvojena na različite načine: ogradom, zidom, živicom i sl. No, takva definicija svakako nije dovoljno konkretna ni precizna jer je vezana uz promjenjive vanjske uvjete.

Pfnür (2005) napominje da se pravno gledano pojam nekretnina ne primjenjuje; ipak, u hrvatskom zakonodavstvu to nije slučaj. Naime, Zakon o vlasništvu i drugim stvarnim pravima iz 2014. nekretnine definira kao čestice zemljine površine, zajedno sa svime što je sa zemljištem trajno spojeno na površini ili ispod nje. Istim zakonom definirano je ustavno i zakonsko najjače stvarno pravo - pravo vlasništva: „Pravo vlasništva stvarno je pravo na određenoj stvari koje ovlašćuje svoga nositelja da s tom stvari i koristima od nje čini što ga je volja te da svakoga drugog od toga isključi, ako to nije protivno tuđim pravima ni zakonskim ograničenjima" (čl. 30. Zakona o vlasništvu i drugim stvarnim pravima iz 2014.).

Također, pojam nekretnina definira Zakon o porezu na promet nekretnina iz 2018. koji u čl. 4/3 navodi: „Nekretnine su zemljišta i građevine“. Ta jednostavna zakonska definicija dobar je temelj za definiranje nekretnina u smislu i svrhu ovog rada gdje se nekretnine promatraju također kao zemljišta i građevine, s tom razlikom da će se za konkretan i jasniji prikaz istraživanja nekretnine gradova podijeliti na stanove, poslovne prostore $\mathrm{i}$ zemljišta.

S ekonomskog stajališta, nekretnine su bitne s pozitivnim ili negativnim predznakom ovisno o tome prepoznaju li i u kojoj mjeri vlasnici svoj utjecaj jer kao posljedicu one donose u jednoj varijanti ekonomsku korist odnosno dobit, dok u drugoj neizbježno donose ekonomsku štetu odnosno gubitke. S obzirom na činjenicu da je država u širem smislu vlasnik najvećeg broja nekretnina, tako su i jedinice lokalne (regionalne) i područne samouprave i gradovi vlasnici mnoštva različitih nekretnina od kojih su neke u funkciji ispunjenja svoje ekonomske i društvene svrhe, ali isto tako postoje brojni slučajevi u kojima mnoge nekretnine ne iskorištavaju svoj potencijal pa tako neiskorištene propadaju te su predmet brige lokalnog stanovništva.

Vrijednost nekretnine zapravo nastaje tijekom vremena korištenjem nekretnine, što kazuje da se vrijednost nekretnine ne može odrediti sama po sebi, već ovisi o učinkovitom ili neučinkovitom korištenju njome, za što su svakako odgovorni njezini vlasnici, odnosno u slučaju gradova predstavnici vlasnika. Pfnür (2005) tu činjenicu opisuje na način da nekretnine nije moguće promatrati samo preko inženjersko-znanstvenoga trodimenzionalnog razgraničenja, nego treba dodati i vrijeme kao integralnu sastavni- 
cu ekonomske definicije nekretnina: nekretnina kao dugoročna prostorna i novčana vrijednost (Real estate as space and money over time). S obzirom na navedeno, nekretnine postaju isplativ financijski oblik tek nakon što se prostorno-vremenske jedinice pretvore u novčano-vremenske jedinice.

Portfelj nekretnina koje gradovi posjeduju u svojem vlasništvu velika je vrijednost, što lokalne samouprave svrstava u najbogatije pravne osobe u Republici Hrvatskoj (Bertović, 2004). Stoga je učinkovito upravljanje nekretninama od vlasnika, u ovom slučaju gradova, ključno za ostvarivanje veće ekonomske i društvene koristi za građane (Guszak, 2007). Jedan je od načina kako je moguće analizirati učinkovito upravljanje nekretninama upravo povrat na nekretnine kojim ćemo se koristiti u daljnjoj analizi u radu.

\section{4. Čimbenici koji utječu na upravljanje nekretninama}

Kao jedan od prvih čimbenika za kvalitetno upravljanje nekretninama u vlasništvu gradova, osim pravnog okruženja, kvalitetne su evidencije o svim pojavnim oblicima nekretnina koje trebaju dati podlogu za primjenu sljedećih devet aspekata upravljanja.

Opisno-tebnički aspekt definira pojavne oblike imovine i njezinu funkcionalnu klasifikaciju. Također, on uređuje opisno-tehničke karakteristike kao i obilježja same nekretnine (npr. naziv, opis, adresa, lokacija, površina, dužina, sobnost, energetski razred itd.). Zatim je potrebno opisati status nekretnine iz nekoliko smjerova, prvi je način stjecanja, dok je drugi opći status.

Geoprostorni aspekt upravljanja nekretninama definira katastarske podatke o nekretnini kao i njezinu prostornu lokaciju (koordinate, oblik). Zatim ju georeferencira i prati povijesni trag promjena nekretnine u prostoru.

Imovinskopravni aspekt sadržava zemljišnoknjižne podatke o nekretnini, upis prava vlasništva i ostalih stvarnih prava (posjeda, služnosti i dr.) kao i sve oblike raspolaganja koji su pravno regulirani.

Financijski aspekt upravljanja nekretninom definira „položaj“ nekretnine u financijskim izvještajima, zatim njezinu vrijednost (knjigovodstvenu, tržišnu i sl.). Posebno je važna analiza i financijsko stanje nekretnine, odnosno praćenje prihoda i rashoda kao i njezin rezultat i stopa kapitalizacije.

Organizacijski aspekt upravljanja nekretninama podrazumijeva nadležnost nad upravljanjem i definirane zadatke kao i standard. Taj aspekt podrazu- 
mijeva znanje i iskustvo u upravljanju te definiranje svih procesa i kolanja dokumentacije kako bi se mogla pratiti sljedivost.

Dokumentacijsko-arbivski aspekt sadržava kompletnu dokumentaciju o nekretnini, digitalno spremljenu i obrađenu, na jednom mjestu centralizirano upravljanje i mogućnost brza uvida u nju.

Izvještajni aspekt upravljanja podrazumijeva analizu podataka i kontrolu njihove kvalitete, zatim izvještavanje o nekretninama po raznim osnovama (vrijeme, vrste, stanje, statusi i efekti upotrebe te prihodi i rashodi).

Društveni aspekt govori o savjesnom i društveno odgovornom upravljanju nekretninama, zatim o brizi za kvalitetno i učinkovito upravljanje na opću dobrobit lokalne zajednice. Aspekt podrazumijeva i transparentno upravljanje kao i uvid u podatke te postizanje zadovoljstva građana savjesnim upravljanjem.

Strateški aspekt upravljanja nekretninama sadržava pripremu, analizu i praćenje planova radi ostvarenja dugoročnih ciljeva. Ulaganje i investicije u nekretnine kao i dugogodišnje očuvanje njihova dobroga funkcionalnog stanja.

Za čelnike gradova navedeno je izazov i upravo se na njihovu razmišljanju u zadanim zakonskim okvirima postiže bolji rezultat ili on izostaje. Čelnik treba razmišljati i odlučivati kao menadžer, a za to mu trebaju upravo menadžerski alati. To sigurno nije kontni plan, neka uputa, ili pak preporuka DUR-a ${ }^{1}$ (dok nije promijenjena uloga DUR-a sa sankcijama za čelnike gradova u slučaju nepostupanja po zadanim preporukama i mišljenjima $)^{2}$ za učinkovitije upravljanje nekretninama u maniri „dobra gospodara“.

Uloga gradova i mogućnost različite upotrebe pojedine nekretnine svakako bi pomogle kada bi bile jasne po svojim funkcionalnim zahtjevima. Tako se u praksi ne rabi (osim u gradovima gdje je proveden koncept metodologije PRLS) ${ }^{3}$ pristup s osnovnim trima klasifikacijskim funkcijama svih pojavnih oblika, npr. nekretnina: A) obvezna, B) diskrecijska i C) imovina za ostvarivanje prihoda.

Svaka pojedina nekretnina treba biti svrstana u jednu od triju navedenih funkcija i nikako u neku četvrtu. Zašto je to važno? Prije svega zato što su

${ }^{1}$ Državni ured za reviziju.

${ }^{2}$ Novi Zakon o državnom uredu za reviziju (NN 25/19) donosi i prekršajne odredbe u čl. 35 .

${ }^{3}$ PRLS kao Projekt reforme lokalne samouprave u RH počeo je 2002. financiran od strane USAID, a u implementaciji The Urban Institutea (v. Bertović, Kaganova, \& Rutledge, 2004). Po toj metodologiji provedeno je oko 100 projekata u jedinicama lokalne samouprave u Hrvatskoj, BiH i Srbiji. 
sasvim drukčija pravila gospodarenja npr. jednim stanom koji u jednom slučaju može biti bitan i potreban kao nekretnina A (npr. kadrovski stan), kao nekretnina B za ostvarivanje nekih socijalnih prava (npr. stanovanje socijalno ugrožene obitelji) te kao nekretnina $\mathrm{C}$ u slučaju kada je tržišni potencijal i kada treba za grad postići maksimalne prihode.

U nastavku rada analizirat će se povrat na nekretnine koji gradovi ostvaruju upravljanjem, što je rezultat ostvarenih prihoda i vrijednosti nekretnina u vlasništvu gradova.

Jedinice lokalne samouprave (dalje u tekstu: gradovi) nalaze se na određenom i jasno definiranom geografskom području s točno određenim granicama. Na navedenom prostoru nalaze se brojne nekretnine, zemljišta na kojima su smještene sve građevine i svi drugi objekti. Nakon osnivanja gradovi su od bivših teritorijalnih jedinica i podjelom starih općina dobili velik broj nekretnina koje trebaju imovinskopravno zbrinuti, njima upravljati i voditi ih u poslovnim knjigama. Osim pravnim sljedništvom gradovi su broj svojih nekretnina smanjivali i/ili povećavali ostalim oblicima raspolaganja (kupnjom, prodajom, darovanjem itd.).

U provedenoj analizi interpretirat će se dobiveni rezultati koji se temelje na povratu na nekretnine (zavisna varijabla) uzimajući u obzir ostale varijable i njihov utjecaj na rezultat upravljanja. Među ostalim, promatrajući zemljopisni položaj Republike Hrvatske, nastojat će se dokazati teza da primorski gradovi imaju veći povrat na nekretnine koje su u njihovu vlasništvu od ostalih gradova. Primorski su gradovi oni koji se svojim rubnim granicama područja nalaze na morskoj obali i/ili je dodiruju. Gradovi koji lokacijom zadovoljavaju uvjet da su smješteni uz morsku obalu svojim položajem imaju veći turistički potencijal u odnosu na gradove koji nisu smješteni uz more. Takav utjecaj možemo tumačiti činjenicom da je Republika Hrvatska turistička zemlja koja u 2017. od prihoda u turizmu ostvaruje 19,7 \% BDP-a (Rihelj, 2018) (sl. 1).

Veća vrijednost nekretnina kao i potražnja za njima upravo na takvim lokacijama dolaze do izražaja i omogućuju vlasnicima bolje prinose. U skladu s time gradovi koji su smješteni uz more uložit će veće resurse u svoje nekretnine kako bi maksimalno iskoristili njihov potencijal.

Gradovi županijskih središta jedinice su lokalne samouprave koje su (osim svojih redovitih djelatnosti zbog svog položaja i normativnog uređenja) i središta svojega regionalnog područja, a takvim položajem jačaju društveni utjecaj i gospodarske aktivnosti u svome geografskom području. 
Slika 1: Prikaz gradova smještenih uz more (žuto su označeni gradovi smješteni uz morsku obalu)

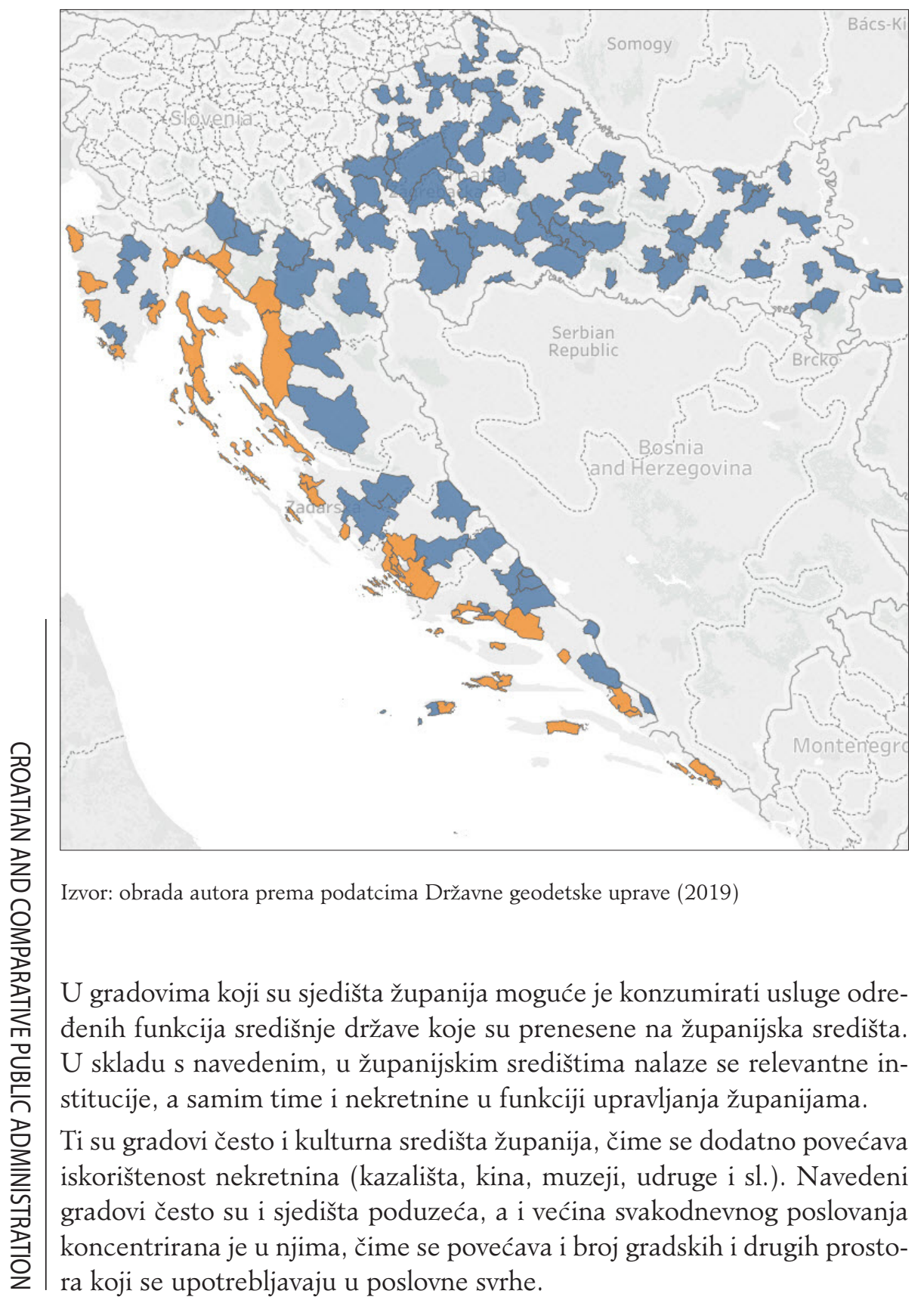




\section{Metodologija}

U ovom dijelu rada prikazuje se odabrani oblik panel-modela koji se rabi u empirijskom istraživanju odrednica povrata na nekretnine u gradovima, s posebnim naglaskom na utjecaj zamjenskih varijabla (proxy) za pokazatelje kvalitete uprave u gradovima. Također, u ovom dijelu rada objašnjen je odabir podataka, njihova konstrukcija te su navedeni izvori.

Empirijsko istraživanje odrednica povrata na nekretnine u hrvatskim gradovima u ovom se radu temelji na metodologiji panel-analize. Generalni oblik panel-modela može se zapisati kao (Greene, 2003):

$$
y_{i t}=x_{i t} \beta+z_{i t}^{\prime} \gamma+w_{i}^{\prime} \alpha+\varepsilon_{i t}
$$

$y_{i t}$ označava zavisnu varijablu, $x_{i t}$ je glavna objašnjavajuća varijabla u modelu, $z_{i t}^{\prime}$ sadržava skup regresora koji imaju ulogu kontrolnih varijabla $\mathrm{u}$ modelu, a heterogenost je među jedinicama promatranja u modelu sadržana u izrazu $w_{i}^{\prime} \alpha$, pri čemu $w_{i}^{\prime}$ sadržava konstantu i set individualnih ili skupnih efekata koji mogu biti opaženi ili neopaženi, a koji su konstantni tijekom vremena. Ta jednadžba definira tri skupine modela, skupnu regresiju (pooled regression), model s fiksnim efektima (fixed effects) i model sa slučajnim efektima (random effects).

U ovom je radu za analizu odabran panel-model sa slučajnim efektima. Odabir modela temelji se na rezultatima Breusch-Pagan LM testa na temelju kojeg se odlučuje o korištenju skupnom regresijom ili modelom sa slučajnim efektima.

Tablica 1: Breusch-Pagan LM test

\begin{tabular}{|l|l|l|}
\hline & Var & sd = sqrt(Var) \\
\hline povrat & 0.0087455 & 0.0935176 \\
\hline $\mathrm{e}$ & 0.0054384 & 0.0737534 \\
\hline $\mathrm{u}$ & 0.0028199 & 0.0531029 \\
\hline $\operatorname{Var}(\mathrm{u})=0$ & \\
\hline Chibar2 $(01)=885.71$ & \\
\hline Prob $>$ chiibar2 $=0.0000$ & \\
\hline
\end{tabular}

Izvor: obrada autora; ispis Stata 14

Modelom s fiksnim efektima u toj se analizi nije moguće koristiti zbog prirode kontrolnih varijabla, što će biti objašnjeno u nastavku. Također, 
važno je istaknuti kako su u modelima korištene robusne greške jer je Woolridgeov test uputio na problem autokorelacije (rezultati testova prikazani su u Tablici 2).

Tablica 2: Woolridgeov test autokorelacije

\begin{tabular}{|l|l|}
\hline \multicolumn{2}{|c|}{ H0: no first-ored autocorrelation } \\
\hline $\mathrm{F}(1,125)$ & 7.151 \\
\hline Prob $>$ F & 0.0085 \\
\hline
\end{tabular}

Izvor: autor; ispis Stata 14

U skladu s navedenim, panel-model sa slučajnim efektima definiran je kao:

$$
\begin{gathered}
y_{i t}=\alpha+x_{i t} \beta+z_{i t}^{\prime} \gamma+u_{i}+\varepsilon_{i t} \\
i=1, \ldots, 126 ; t=2005, \ldots, 2017
\end{gathered}
$$

Kao zavisna varijabla u ovom se radu upotrebljava varijabla porrat na nekretnine. Dvije su temeljne objašnjavajuće varijable koje odražavaju institucijsku kvalitetu gradova, poduzetnička aktivnost te transparentnost proračuna. ${ }^{4}$ Kontrolne su varijable korištene $u$ analizi pokazatelj nezaposlenosti, fiskalni kapacitet, lokacija (grad na moru ili kontinentalni grad) te sjedište (je li grad sjedište županije). Analiza je provedena na uzorku od 126 gradova od 2005. do 2017. godine. U Republici Hrvatskoj postoji 128 gradova, ali su Kutjevo i Popovača isključeni iz analize u ovom radu. Uzrok isključenja Grada Kutjeva nedostatak je podataka i pogreške u podatcima u proračunu, dok je Grad Popovača isključen iz analize jer je dobio status grada u travnju 2013., odnosno u drugoj polovini analiziranoga dvanaestogodišnjeg razdoblja.

Prva objašnjavajuća varijabla, poduzetnička aktivnost (broj poduzetnika po stanovniku), upotrebljava se kao zamjenska (proxy) varijabla za kvalitetu gradske uprave. Odabir te varijable temelji se na konceptu javnog izbora tzv. glasanja nogama (voting with the feet) koji je definirao Tiebout (1956). U tom se kontekstu može pretpostaviti kako poduzetnici unutar iste zemlje mogu bez prepreka registrirati poduzeća u lokalnim jedinicama koje prepoznaju kao one koje im nude kvalitetniju javnu uslugu. U

\footnotetext{
${ }^{4}$ Procjenjuju se dva zasebna modela u ovisnosti o glavnoj objašnjavajućoj varijabli.
} 
skladu s navedenom metodologijom i definiranom varijablom ispituje se utječe li broj poduzetnika na povrat na nekretnine gradova.

Odabir druge objašnjavajuće varijable, transparentnost proračuna, temelji se na pretpostavci da gradovi koji imaju odgovorniju fiskalnu vlast (veća transparentnost proračuna) imaju i transparentan odnos s poduzetnicima i građanima, što oni prepoznaju kao kvalitetniju gradsku vlast. $\mathrm{U}$ radu se upotrebljavaju proxy varijable za kvalitetu gradske uprave jer ne postoji javno dostupan, sustavan skup pokazatelja kvalitete gradske uprave. Iz navedenog će se testirati ostvaruju li gradovi s većom transparentnošću proračuna viši povrat na nekretnine. Na razini županija može se upotrebljavati indeks konkurentnosti županija, ali on je dostupan za relativno malen broj godina, a i broj županija znatno je manji od broja gradova, što otežava empirijsku analizu. U radu se očekuje da bolji pokazatelji institucijske kvalitete imaju pozitivan utjecaj na pokazatelj povrata na nekretnine.

Kontrolne varijable uključene su u model kako bi se smanjila mogućnost utjecaja pristranosti izostavljenih važnih objašnjavajućih varijabla (omitted variable bias). Kao prva važna kontrolna varijabla u modelu odabran je pokazatelj nezaposlenosti kao pokazatelj ekonomske aktivnosti u gradu s obzirom na to da se može pretpostaviti da u slučaju nepovoljnih ekonomskih uvjeta padaju prihodi od nekretnina, a također može doći do revizije vrijednosti nekretnina nadolje. Sljedeća je kontrolna varijabla fiskalni kapacitet, što je odabrano uz pretpostavku da gradovi s većim fiskalnim kapacitetom bolje upravljaju prihodima proračuna. Tu je i kontrolna varijabla lokacija, koja je definirana kao kvalitativna varijabla koja poprima vrijednost 1 u slučaju da je grad lociran uz more. U radu se pretpostavlja da gradovi smješteni uz more zbog većega turističkog potencijala imaju bolju iskorištenost nekretnina, što utječe i na povrate. Konačno, kao kontrolna varijabla u analizi se rabi i varijabla sjedište, koja je također definirana kao kvalitativna varijabla koja poprima vrijednost 1 u slučaju da je grad i sjedište županije. Pretpostavka je u radu da gradovi koji su sjedišta županija imaju više nekretnina u funkciji jer su gospodarska, administrativna i financijska središta. Odabir posljednjih dviju varijabla, koje mogu znatno utjecati na iskorištenost nekretnina, onemogućava korištenje modelom s fiksnim efektima jer je riječ o varijablama koje su konstantne u vremenu. 


\section{Podatci}

U radu se upotrebljavaju sekundarni izvori podataka, preuzeti iz javno dostupnih izvora. Podatci o vrijednosti nekretnina preuzeti su iz izvještaja Ministarstva financija kao i podatci o prihodima od nekretnina i fiskalnom kapacitetu, pokazatelji nezaposlenosti iz Hrvatskog zavoda za zapošljavanje, a podatci o poduzetničkoj aktivnosti iz Državnog zavoda za statistiku i Fine. Kvalitativne varijable definirane su na temelju odgovarajućih zakona. Iscrpan opis i objašnjenja varijabla dani su u Tablici 3.

\section{Tablica 3: Definicije i izvori podataka}

\begin{tabular}{|c|c|c|}
\hline $\begin{array}{c}\text { Naziv } \\
\text { varijable }\end{array}$ & Definicija varijable & Način mjerenja \\
\hline $\begin{array}{l}\text { Vrijed- } \\
\text { nost } \\
\text { nekret- } \\
\text { nina }\end{array}$ & $\begin{array}{l}\text { Vrijednost nekretnina vrijednost je } \\
\text { imovine iskazana u bilanci na dan } \\
\text { 31. } 12 \text {. koja se ubraja u skupinu } 01 \\
\text { nefinancijska imovina i podskupinu } \\
011 \text { materijalna imovina - prirodna } \\
\text { bogatstva, odjeljak } 0111 \text { zemljište } \\
\text { te skupinu } 02 \text {, podskupinu } 21 \text {, } \\
\text { odjeljak } 0211 \text { stambeni objekti i } \\
\text { odjeljak } 0212 \text { poslovni objekti. }\end{array}$ & $\begin{array}{l}\text { Varijabla se izražava kao broj koji je } \\
\text { ukupna vrijednost nekretnina. } \\
\text { Izvor: Ministarstvo financija (2019a) }\end{array}$ \\
\hline \multirow[t]{5}{*}{$\begin{array}{l}\text { Prihod } \\
\text { od ne- } \\
\text { kretnina }\end{array}$} & $\begin{array}{l}\text { Prihod od nekretnina ukupan je } \\
\text { iznos prihoda iskazanih u izvještaju } \\
\text { PR-RAS, funkcijski, razina 22, koji }\end{array}$ & \multirow[t]{5}{*}{$\begin{array}{l}\text { Varijabla se izražava kao broj koji } \\
\text { mjeri prihod od nekretnina. } \\
\text { Izvor: Ministarstvo financija (2019) }\end{array}$} \\
\hline & $\begin{array}{l}\text { prihodi imovine (razred 64), } \\
\text { prihodi od nefinancijske imovi- } \\
\text { ne (podskupina 642), prihod za } \\
\text { zakupa i iznajmljivanja imovine } \\
\text { (odjeljak 6422) }\end{array}$ & \\
\hline & $\begin{array}{l}\text { prihodi od prodaje neproizvedene } \\
\text { dugotrajne imovine (razred 71), } \\
\text { prirodna bogatstva (podskupina } \\
711 \text { ), zemljišta (odjeljak 7111) }\end{array}$ & \\
\hline & $\begin{array}{l}\text { prihodi od prodaje proizvedene } \\
\text { dugotrajne imovine (razred 72), } \\
\text { prihod od prodaje gradevinskih } \\
\text { objekata (podskupina 721), stam- } \\
\text { beni objekti (odjeljak 7211). }\end{array}$ & \\
\hline & $\begin{array}{l}\text { Prihodi od prodaje proizvedene } \\
\text { dugotrajne imovine (razred 72), } \\
\text { prihod od prodaje gradevinskih } \\
\text { objekata (podskupina 721), poslov- } \\
\text { ni objekti (odjeljak 7212). }\end{array}$ & \\
\hline
\end{tabular}




\begin{tabular}{|c|c|c|}
\hline $\begin{array}{l}\text { Poka- } \\
\text { zatelj } \\
\text { povrata } \\
\text { na ne- } \\
\text { kretnine }\end{array}$ & $\begin{array}{l}\text { Povrat na nekretnine prikazu- } \\
\text { je novčane tokove iz upotrebe } \\
\text { nekretnina. }\end{array}$ & $\begin{array}{l}\text { Varijabla je izračunana kao omjer } \\
\text { prihoda od nekretnina i vrijednosti } \\
\text { nekretnina. } \\
\text { Varijabla vrijednost nekretnina - } \\
\text { izražava se kao broj koji je ukupna } \\
\text { vrijednost nekretnina. } \\
\text { Izvor: Ministarstvo financija (2019a) } \\
\text { Varijabla prihod od nekretnina - } \\
\text { izražava se kao broj koji mjeri prihod } \\
\text { od nekretnina. } \\
\text { Izvor: Ministarstvo financija (2019) }\end{array}$ \\
\hline $\begin{array}{l}\text { Gradovi } \\
\text { sjedišta } \\
\text { Županija }\end{array}$ & $\begin{array}{l}\text { Zakon o područjima županija, } \\
\text { gradova i općina u Republici } \\
\text { Hrvatskoj definira koji su gradovi } \\
\text { sjedišta županija. }\end{array}$ & $\begin{array}{l}\text { Varijabla je definirana kao binarna } \\
\text { varijabla koja će poprimiti vrijednost } \\
1 \text { za gradove sjedišta županija i } 0 \text { za } \\
\text { ostale gradove. Izvor: Zakon o po- } \\
\text { dručjima županija, gradova i općina } \\
\text { u Republici Hrvatskoj iz 2006. s } \\
\text { izmjenama }\end{array}$ \\
\hline $\begin{array}{l}\text { Lokacija } \\
\text { gradova }\end{array}$ & $\begin{array}{l}\text { Lokacije gradova na obali mora oni } \\
\text { su gradovi koji se svojim rubnim } \\
\text { granicama područja nalaze na } \\
\text { morskoj obali i/ili je dodiruju. }\end{array}$ & $\begin{array}{l}\text { Varijabla je definirana kao binarna } \\
\text { varijabla koja će poprimiti vrijednost } \\
1 \text { za gradove uz more i } 0 \text { za ostale } \\
\text { gradove. } \\
\text { Izvor: Državna geodetska uprava } \\
\text { (2019) }\end{array}$ \\
\hline $\begin{array}{l}\text { Poka- } \\
\text { zatelj } \\
\text { nezapo- } \\
\text { slenosti }\end{array}$ & $\begin{array}{l}\text { Pokazatelj nezaposlenosti prika- } \\
\text { zuje koliki je udio stanovništva u } \\
\text { pojedinom gradu u promatranoj } \\
\text { godini bio nezaposlen. }\end{array}$ & $\begin{array}{l}\text { Varijabla se definira kao omjer } \\
\text { ukupna broja nezaposlenih i ukupna } \\
\text { broja stanovnika u pojedinom gradu. } \\
\text { Izvor: Hrvatski zavod za zapošljava- } \\
\text { nje (2019) }\end{array}$ \\
\hline $\begin{array}{l}\text { Broj } \\
\text { podu- } \\
\text { zetnika } \\
\text { (podu- } \\
\text { zetnička } \\
\text { aktiv- } \\
\text { nost) }\end{array}$ & $\begin{array}{l}\text { Broj poduzetnika broj je aktivnih } \\
\text { gospodarskih subjekata koji su } \\
\text { u Registar godišnjih financijskih } \\
\text { izvještaja dostavili u roku potpun i } \\
\text { točan godišnji financijski izvještaj } \\
\text { na području gradova. }\end{array}$ & $\begin{array}{l}\text { Varijabla će se mjeriti aktivnim bro- } \\
\text { jem poduzetnika prema podatcima iz } \\
\text { registra Fine normaliziranim brojem } \\
\text { stanovnika na temelju podataka Dr- } \\
\text { žavnog zavoda za statistiku, pri čemu } \\
\text { je Grad Zagreb = } 100 \text {. } \\
\text { Izvor: Financijska agencija, Državni } \\
\text { zavod za statistiku, podatci dostavlje- } \\
\text { ni } 20.6 \text {. } 2019 \text {. }\end{array}$ \\
\hline $\begin{array}{l}\text { Fiskalni } \\
\text { kapaci- } \\
\text { tet }\end{array}$ & $\begin{array}{l}\text { Fiskalni kapacitet sposobnost je } \\
\text { gradova da vlastitim proračunskim } \\
\text { sredstvima financiraju proračunske } \\
\text { rashode. }\end{array}$ & $\begin{array}{l}\text { Varijabla se mjeri kao odnos ukupna } \\
\text { prihoda poslovanja i broja stanovnika } \\
\text { u pojedinom gradu. } \\
\text { Izvor: Ministarstvo financija, Mini- } \\
\text { starstvo financija (2019a), Državni } \\
\text { zavod za statistiku (2019) }\end{array}$ \\
\hline $\begin{array}{l}\text { Transpa- } \\
\text { rentnost }\end{array}$ & $\begin{array}{l}\text { Proračunska transparentnost } \\
\text { gradova podrazumijeva uvid u } \\
\text { potpune, točne, pravovremene i ra- } \\
\text { zumljive informacije o proračunu. }\end{array}$ & $\begin{array}{l}\text { Sekundarni podatci } \\
\text { Varijabla će biti preuzeta iz publika- } \\
\text { cije i baze podataka Transparentnost } \\
\text { proračuna lokalnih jedinica. Izvor: } \\
\text { Institut za javne financije (2019) }\end{array}$ \\
\hline
\end{tabular}

Izvor: obrada autora 


\section{Rezultati}

Tablica 4 prikazuje utjecaj poduzetničke aktivnosti na povrat na nekretnine u gradovima. Taj je učinak pozitivan i statistički vrijedan, što je u skladu s pretpostavkom da se gradovi koji imaju kvalitetniji institucijski okvir, a time i veći broj poduzetnika po stanovniku bolje koriste raspoloživim nekretninama, što im omogućava veći povrat. Od kontrolnih varijabla znatan utjecaj ima pokazatelj nezaposlenosti stanovništva koji pokazuje da gradovi s višom nezaposlenošću (nepovoljnijim gospodarskim uvjetima) ostvaruju manji povrat na nekretnine. Također, rezultati pokazuju statistički bitan utjecaj lokacije na povrat na nekretnine, pri čemu treba podsjetiti na to da je ta kontrolna varijabla konstruirana tako da poprima vrijednost 1 u slučaju da se grad nalazi na moru. Iz navedenog se može zaključiti da gradovi koji se nalaze na moru ostvaruju viši povrat na nekretnine, što se, barem djelomično, može objasniti turističkom aktivnošću. Procijenjeni koeficijenti uz varijable fiskalni kapacitet i status županije imaju očekivan pozitivan predznak, ali on nije statistički važan.

Tablica 4: Utjecaj poduzetničke aktivnosti na porrat na nekretnine

\begin{tabular}{|c|c|c|c|c|c|}
\hline povrat & Coef. & St.Err & $\mathrm{t}$-value & p-value & Sig. \\
\hline gustoća poduzetništva & 0.047 & 0.008 & 6.02 & 0.000 & $* * *$ \\
\hline nezaposlenost & -0.697 & 0.174 & -4.00 & 0.000 & $* * *$ \\
\hline fiskalni kapacitet & 0.003 & 0.003 & 0.88 & 0.377 & \\
\hline županija & 0.003 & 0.013 & 0.25 & 0.804 & \\
\hline lokacija & 0.063 & 0.017 & 3.65 & 0.000 & $* * *$ \\
\hline _cons & 0.161 & 0.023 & 7.12 & 0.000 & $* * *$ \\
\hline
\end{tabular}

\begin{tabular}{|l|r|l|r|}
\hline Mean dependent var & 0.066 & SD dependent var & 0.094 \\
\hline Overall r-squared & 0.016 & Number of obs & 1512.000 \\
\hline Chi-square & 52.632 & Prob > chi2 & 0.000 \\
\hline R-squared within & 0.134 & R-squared between & 0.002 \\
\hline
\end{tabular}

*** $\mathrm{p}<0.01,{ }^{* *} \mathrm{p}<0.05,{ }^{*} \mathrm{p}<0.1$

Izvor: obrada autora prema podatcima Hrvatskog zavoda za zapošljavanje (2019), Ministarstva financija (2019a), Državnog zavoda za statistiku (2019) i Državne geodetske uprave (2019) 
U Tablici 5 prikazani su rezultati drugog modela. Ta tablica prikazuje utjecaj transparentnosti proračuna ${ }^{5}$ kao druge važne proxy varijable za kvalitetu institucijskog okvira u gradovima na povrat na nekretnine u gradovima. Taj učinak također je pozitivan i statistički vrijedan, što je u skladu s pretpostavkom da se gradovi koji imaju kvalitetniji institucijski okvir bolje koriste raspoloživim nekretninama, što im omogućava veći povrat.

Tablica 5: Utjecaj transparentnosti proračuna na porrat na nekretnine

\begin{tabular}{|l|r|r|r|r|r|}
\hline \multicolumn{1}{|c|}{ povrat } & \multicolumn{1}{c|}{ Coef. } & \multicolumn{1}{c|}{ St.Err } & t-value & p-value & \multicolumn{1}{c|}{ Sig. } \\
\hline transparentnost & 0.010 & 0.001 & 8.86 & 0.000 & $* * *$ \\
\hline nezaposlenost & -0.524 & 0.144 & -3.63 & 0.000 & $* * *$ \\
\hline fiskalni kapacitet & 0.002 & 0.002 & 1.07 & 0.286 & \\
\hline županija & 0.003 & 0.010 & 0.30 & 0.767 & \\
\hline lokacija & 0.029 & 0.014 & 2.01 & 0.045 & $* *$ \\
\hline _cons & 0.111 & 0.018 & 6.24 & 0.000 & $* * *$ \\
\hline
\end{tabular}

\begin{tabular}{|l|r|l|r|}
\hline Mean dependent var & 0.066 & SD dependent var & 0.094 \\
\hline Overall r-squared & 0.046 & Number of obs & 1512.000 \\
\hline Chi-square & 97.313 & Prob > chi2 & 0.000 \\
\hline R-squared within & 0.060 & R-squared between & 0.037 \\
\hline
\end{tabular}

${ }^{* * *} \mathrm{p}<0.01,{ }^{* *} \mathrm{p}<0.05,{ }^{*} \mathrm{p}<0.1$

Izvor: obrada autora prema podatcima Hrvatskog zavoda za zapošljavanje (2019), Ministarstva financija (2019), Državnog zavoda za statistiku (2019), Državne geodetske uprave (2019) i Zakona o područjima županija, gradova i općina u Republici Hrvatskoj iz 2006. s izmjenama

$\mathrm{Na}$ temelju navedenog može se zaključiti da gradovi s višom razinom transparentnosti proračuna ostvaruju veći povrat na nekretnine. Od kontrolnih varijabla i u tom modelu znatan utjecaj ima pokazatelj nezaposlenosti stanovništva koji pokazuje da gradovi s višom nezaposlenošću ostvaruju niži povrat na nekretnine. Dodatno, rezultati ponovno upućuju na statistički vrijedan utjecaj lokacije na povrat na nekretnine. Procijenjeni koeficijenti uz varijable fiskalni kapacitet i status županije imaju očekivan pozitivan predznak, ali on nije statistički bitan.

${ }^{5}$ U ovom dijelu rada upotrebljava se nebalansirani panel-model jer su podatci o transparentnosti proračuna dostupni samo za 2015., 2016. i 2017. godinu. 
Tablica 6: Korelacijsa matrica neovisnib varijabla

\begin{tabular}{|l|c|c|c|c|}
\hline & nezaposlenost & $\begin{array}{c}\text { fiskalni } \\
\text { kapacitet }\end{array}$ & $\begin{array}{c}\text { gustoća } \\
\text { poduzetništva }\end{array}$ & transparentnost \\
\hline nezaposlenost & 1.00 & -0.46 & -0.55 & -0.34 \\
\hline fiskalni kapacitet & -0.46 & 1.00 & 0.62 & 0.19 \\
\hline gustoća poduzetništva & -0.55 & 0.62 & 1.00 & 0.36 \\
\hline transparentnost & -0.34 & 0.19 & 0.36 & 1.00 \\
\hline
\end{tabular}

Izvor: obrada autora prema podatcima Hrvatskog zavoda za zapošljavanje (2019), Ministarstva financija (2019a), Državnog zavoda za statistiku (2019); podatke su 20. 6. 2019. dostavili Financijska agencija, Državni zavod za statistiku i Institut za javne financije (2019)

Rezultati korelacijske analize ne pokazuju problem multikolineranosti. Naime, apsolutna vrijednost koeficijenata korelacije kreće se od 0,19 do 0,62 , što je moguće interpretirati kako se korelacije varijabla kreću od slabe do umjerene pozitivne (negativne) linearne povezanosti (v. Ratner, 2009).

Tablica 7: Deskriptivna statistika neovisnih varijabla

\begin{tabular}{|c|c|c|c|c|}
\hline & nezaposlenost & $\begin{array}{l}\text { fiskalni } \\
\text { kapacitet }\end{array}$ & $\begin{array}{c}\text { gustoća } \\
\text { poduzetništva }\end{array}$ & transparentnost \\
\hline Mean & 0.07 & 4008 & 18961 & 2.9 \\
\hline Median & 0.06 & 3466 & 14794 & 3.0 \\
\hline Maximum & 0.16 & 12328 & 65102 & 5.0 \\
\hline Minimum & 0.02 & 1334 & 3433 & 0.0 \\
\hline Std. Dev. & 0.03 & 1986 & 11529 & 1.6 \\
\hline Skewness & 0.57 & 1 & 2 & -0.5 \\
\hline Kurtosis & 2.56 & 4 & 6 & 2.1 \\
\hline
\end{tabular}

Izvor: obrada autora prema podatcima Hrvatskog zavoda za zapošljavanje (2019), Ministarstva financija (2019), Državnog zavoda za statistiku (2019); podatke su 20. 6. 2019. dostavili Financijska agencija, Državni zavod za statistiku i Institut za javne financije (2019)

\section{Zaključak}

Upravljanje imovinom jedinica lokalne samouprave u Republici Hrvatskoj, kao i u većem dijelu regije, velik je izazov u svakom pogledu - kao pravni okvir, kao kontinuitet u razvoju društva, kao važno tranzicijsko 
pitanje, kao metodologija evidentiranja i dokazana dobra praksa upravljanja. Tranzicijskim promjenama prije 25 godina nastale su znatne promjene u pristupu upravljanju nekretninama gradova, pri čemu se postižu spori napredci u ispunjenju temeljnog uvjeta za uspješnije upravljanje nekretninama, a to su sređene evidencije o vrsti, namjeni, broju, vrijednosti te prihodima i rashodima na imovini.

Potrebno je istaknuti da je u literaturi vrlo teško naći slična istraživanja, što je ujedno i jedan od temeljnih doprinosa ovog rada. U radu su prikazana istraživanja u kojima se analiziraju različiti aspekti upravljanja imovinom u gradovima, ali prema saznanju, dosad nisu empirijski istraživane odrednice povrata na imovinu u gradovima. Osim literature, u dijelu podataka postoji ograničenje jer su podatci o transparentnosti proračuna dostupni samo za 2015., 2016. i 2017. godinu te se iz navedenog razloga rabi nebalansirani panel-model.

Navedeni rezultati istraživanja potvrđuju da povoljniji institucijski okvir u gradovima pozitivno utječe na povrat na nekretnine jer ima pozitivan utjecaj na gospodarsku aktivnost u gradovima. Veća gospodarska aktivnost podrazumijeva veći stupanj iskorištenosti nekretnina, što ima pozitivan utjecaj na prihode od nekretnina, a time i na pokazatelj povrata na nekretnine.

Upravo iz prethodno provedenog istraživanja i navedenog zaključka, a u vezi s različitim vrstama nekretnina koje su u vlasništvu gradova, u skladu s ciljevima financijske politike vezane za tu vrstu imovine u daljnjem upravljanju treba:

- maksimalizirati učinkovitost nekretnina

- minimizirati troškove zadržavajući kvalitetu nekretnina na zadovoljavajućoj razini

- identificirati, analizirati i minimizirati indirektne subvencije na sve nekretnine

- maksimalizirati neto prihode i primijeniti tržišna načela u upravljanju nekretninama

- decentralizirati upravljanje nekretninama, odnosno prepustiti vlasništvo i upravljanje nad nekretninama koje su trenutačno u vlasništvu središnje države lokalnoj samoupravi.

Bez sređenih evidencija o nekretninama nemoguće je njima učinkovito upravljati. Nadalje, sređivanje evidencija, javno provođenje svih postupaka vezanih za upravljanje i raspolaganje (zakupi, najmovi, zamjene, prodaje, korištenje s valjanom pravnom osnovom i dr.) iznimno je bitno za transparentno upravljanje koje građani mogu prepoznati i dati sasvim 
drukčiju potporu lokalnoj vlasti (izborima, referendumima, ali i drugim oblicima odlučivanja). Tako se dostižu potrebna kontrola i odgovornost u upravljanju i raspolaganju nekretninama koju iznimno brzo može prepoznati i privatni sektor u kontekstu povjerenja za ulaganja i gospodarski razvoj, što dalje znači povećano zapošljavanje i sveukupni viši standard života u lokalnoj zajednici.

Vremenska dimenzija uzorka (2005. - 2017.) ovog istraživanja jedno je od njegovih temeljnih ograničenja. Može se uočiti da je broj opažanja u pojedinačnim opservacijama relativno visok, ali problem je što se analizira u razdoblju znatno obilježenom recesijom. U budućim se istraživanjima također može koristiti navedenom metodologijom, s tim da se čimbenici mogu proširivati ovisno o dostupnosti podataka.

\section{Popis literature}

Bajo, A., \& Ignjatović, M. (2018). Establishing a central registry of state assets: third time lucky? Press release, 11(105), 1-3, https://doi.org/10.3326/pr.2018.105.

Banner, D. K., \& Gagne, T. E. (1995). Designing effective organizations: Traditional \& transformational views. Thousand Oaks, California, USA: Sage Publications, https://doi.org/10.1177/017084069501600423.

Bertović, H. (2004.). Rezultati programa sufinanciranja - Model upravljanja imovinom. Zagreb, Hrvatska: The Urban Institute.

Bertović, H., Kaganova, O., \& Rutledge, J. (2004). Priručnik za upravljanje imovinom u jedinicama lokalne i područne (regionalne) samouprave. Zagreb, Hrvatska: The Urban Institute i Savez Udruge gradova i Udruge općina Republike Hrvatske.

Dent, P. (2014). Managing public sector property assets: the valuation issues. Property Management 15(4), 226-233, https://doi.org/10.1108/02637479710187062.

Državna geodetska uprava (2019). Geoportal Držarne geodetske uprave. Dostupno na https://geoportal.dgu.hr/.

Državni zavod za statistiku (2019). Popis stanorništva Republike Hrvatske. Dostupno na https://www.dzs.hr/Hrv/censuses/census2011/censuslogo.htm.

Edwards, V., \& Ellison, L. (2009). Corporate property management: aligning real estate with business strategy. New Jersey, USA: John Wiley \& Sons.

Greene, W. H. (2003). Econometric analysis. New Jersey, USA: 1Ed Pearson Education India.

Guszak, I. (2007). Outsourcing IT usluga - registar nekretnina. U I. Guszak (ed.), Outsourcing u gradovima i općinama (str. 34-36). Zagreb, Hrvatska: The Urban Institute.

Hanis, M. H., Trigunarsyah, B., \& Susilawati, C. (2010). The significant of public asset management framework application for Indonesian local governments: Opportunities and challenges. In Proceedings of 1st Makassar International 
Conference On Civil Engineering (1185-1192). Dostupno na http://eprints.qut. edu.au/32581/.

Hentschel, J., \& Kaganova, O. (2007). Government property resources: A case for asset management. Public Management, 89(2), 24-26.

Hrvatski zavod za zapošljavanje (2019). Pokazatelii nezaposlenosti. Dostupno na https://statistika.hzz.hr/Statistika.aspx?tipIzvjestaja=1.

Institut za javne financije (2019). Transparentnost lokalnib proračuna. Dostupno na https://www.ijf.hr/transparentnost/?params_1=transparentnost.

Kaganova, O., McKellar, J., \& Peterson, G. (2006). Introduction. U O. Kaganova, $\&$ J. McKellar (eds.), Managing government property assets: International experiences (1 ed) (str. 1-24). Washington D. C., USA: The Urban Institute Press.

Kaganova, O., Tian, V., \& Undeland, C. (2001). Learning how to be efficient property owners and accountable governments: The case of Kyrgyzstan's cities. Public Administration and Development: The International Journal of Management Research and Practice, 21(4), 333-341.

Kask, K. (2014). Public sector real estate asset management models and their evaluation. Neobjavljena doktorska disertacija. Tartu, Estonija: Faculty of Economics and Business Administration, University of Tartu.

Kontrec, D. (2014). Pravni status i raspolaganje poljoprivrednim zemljištem u Republici Hrvatskoj - povijesni prikaz, de lege lata, de lege ferenda. Radovi Zavoda za znanstveni rad Varaždin (25), 69-95, https://doi.org/10.21857/ y26kec36g9.

Ministarstvo financija (2019). Lokalna samouprava, Financijski izvještaji, PR-RAS, razdoblje 2002. - 2018. Dostupno na http://www.mfin.hr/hr/financijski-izvjestaji-jlprs.

Ministarstvo financija (2019a). Lokalna samouprava, Financijski izvještaji, Bilance, razdoblje 2002. - 2018. Dostupno na http://www.mfin.hr/hr/financijski-izvjestaji-jlprs.

Pfnür, A. (2005). Moderni menadžment nekretnina. Facility Management $i$ Corporate Real Estate Management. Zagreb, Hrvatska: Koraci, https://doi. org/10.1108/1463 0011011074768.

Phelps, A. (2010). Rationale, practice and outcomes in municipal property asset management. Journal of Corporate Real Estate, 12(3), 157-174.

Ratner, B. (2009). A closer look the correlation coefficient: Its values range between $+1 / \sim 1$, or do they?. Journal of Targeting, Measurement and Analysis for Marketing, 17, 139-142, https://doi.org/10.1057/jt.2009.5.

Rihelj, G. (2018). Prošle godine ostvaren rast priboda od turizma od 10 posto, što čini 18,6 posto BDP-a. Dostupno na https://hrturizam.hr/prosle-godine-ostvarenrast-prihoda-od-turizma-od-10-posto-sto-cini-196-posto-bdp/.

Simonetti, P. (2010). Vlasništvo i njegove transformacije, jamstvo i zaštita u ustavnom poretku Republike Hrvatske. Zbornik Pravnog fakulteta u Rijeci, 31(1), 336-364.

Thorncroft, M. (1965). Principles of estate management. London, UK: Estates Gazette Limited. 
Tiebout, C. M. (1956). A pure theory of local expenditures. Journal of political economy, 64(5), 416-424, https://doi.org/10.1086/257839.

Vašiček, D. (2015). State property management in the function of the competitiveness of the Croatian economy. U V. Kandžija (ur.), Razvoj gospodarske konkurentnosti Republike Hrvatske kao članice EU (str. 426-461). Rijeka, Hrvatska: Ekonomski fakultet.

Wilson, A. (2013). Asset management focusing on developing maintenance strategies and improving performance. Surrey, UK: Polyteknisk Boghandel og Forlag.

\section{Pravni izvori}

Zakon o državnom uredu za reviziju, NN 25/19.

Zakon o područjima županija, gradova i općina u Republici Hrvatskoj, NN 86/06, 25/06, 16/07, 95/08, 46/10, 145/10, 37/13, 44/13, 45/13, 110/15.

Zakon o porezu na promet nekretnina, NN 115/11 i 106/18.

\section{SUCCESS FACTORS OF URBAN PROPERTY MANAGEMENT IN CROATIA}

\section{Summary}

Local self-government units in the Republic of Croatia own a large number of different types of property. Real estate represents the most valuable form of income in the non-financial property portfolio. It is considered property of the bighest value, which is disposed of and managed by the cities. Such real estate is the indirect ownership of all citizens, making the insurance of its effective management important. This paper shows the poor use of real estate as a city's source of financing, reflected in the indicator of return which the cities realise on the basis of the real estate in their ownership. Using panel regression, the paper empirically explores the indicators of return on real estate in Croatian cities in the period between 2005 and 2017, with particular emphasis on the quality of city administration as an important indicator of the utilisation of real estate. Due to the lack of credible and publicly available indicators on the quality of the cities' administration, this paper uses the number of entrepreneurs per capita as a proxy variable for the quality of the cities' administration. This approach is based on the Tiebout model of foot voting.

Keywords: management quality, real estate, cities, management efficiency, return on real estate 